\title{
MENGGUGURKAN KANDUNGAN HASIL PEMERKOSAAN MENURUT YUSUF AL-QARDHAWI
}

Oleh:

\author{
M.Aminullah
}

amienmuhammad.ma@gmail.com

Dosen IAI Muhammadiyah Bima

\begin{abstract}
:
The main point of this essay is the study of Islamic Law about "Perspective of Yusuf Al-Qardhawi at abort the fetus which is effected by rape". The problem formulations are; firstly what is the law of abort the fetus which effected by rape based on Yusuf Al-Qardhawi's perspective?, second what the kind of approach to take and set the law by Yusuf Al-Qardhawi to that case? The writer uses the multidisciplinary approach, the instruments of data analyze are deductive, inductive and collaborative. While, to collect the data, writer used the literature approach.

The result of this research show that, firstly the law of abort the fetus effected by rape is allowed or legalized based on Yusuf AlQardhawi's perspective, it to be rukhsah to who pregnant due to the rape, except it, if not aborted so will disturb the pregnant safety. But, abort should be done before 40 days of fetus age.

Second, Yusuf Al-Qardawi used the Qiyas method to decide the case, it mean that the woman is allowed to abort in an emergency. If it not, so will disturb the pregnant safety, as known that, the core of pregnant is fetus. Finally, the result of research describe how moderate of Yusuf Al-Qardawi to get the benefit of human.
\end{abstract}

Keyword: Law, Abort, Rape, Yusuf Al-Qardhawi.

\section{Pendahuluan}

Salah satu permasalahan yang paling sering muncul adalah menggugurkan kandungan hasil dari pemerkosaan. Apabila hukum dari permasalahan tersebut dicari di dalam Alquran maupun hadis secara khusus, maka tidak akan ditemukan hukumnya. Oleh sebab itu, para ulama yang berada pada zaman tersebut sudah seharusnya mengerahkan pikiran dan usaha mereka dalam upaya pencarian dan penetapan hukum dari permasalahan-permasalahan tersebut, baik itu dengan menggunakan metode ijma $\bar{a}^{\prime}$ maupun qiyas terhadap masalahmasalah yang sebelumnya telah ada dan ditetapkan dalam Alquran 
maupun hadis, sehingga dapat memberikan penjelasan tentang hukum dari permasalahan-permasalahn baru tersebut.

Berbicara tentang metode penetapan hukum, maka tidak akan pernah lepas dari kaidah-kaidah ușuliyah, kaidah-kaidah fighiyah, maupun maqāssid al-syariah. Karena dengan tiga hal tersebutlah para ulama mampu dan bisa menyimpulkan permasalahan yang mereka hadapi, yang apabila para ulama tidak menggunakannya maka akan sulit bagi mereka untuk menemukan titik kebenaran dalam penyimpulan hukum.

Menggugurkan kandungan (aborsi), menggugurkan kandungan yang dalam bahasa arabnya al-ijhād (الاجهاض) atau isqāt alhamli (اسقاط الحمل); menurut Dr. Muhammad Ali al-Bārr adalah keluarnya janin dari dalam kandungan sebelum sampai 20 minggu. ${ }^{1}$ Sedangkan menurut Shalāh Karīm, al-ijhạ̈ atau menggugurkan kandungan adalah berakhirnya masa kehamilan sebelum minggu ke 28.2 Di dalam Kamus Besar Bahasa Indonesia (KBBI) juga dijelaskan bahwa, kata menggugurkan kandungan terdiri dari dua kosa kata; yaitu menggugurkan dan kandungan. Kata menggugurkan sendiri berasal dari kata dasar gugur yang berarti jatuh sebelum masak, lahir sebelum waktunya, runtuh, batal atau tidak jadi dan tidak berlaku lagi, sedangkan menggugurkan artinya menyebabkan (menyatakan) gugur atau sengaja mengeluarkan janin sebelum waktunya. ${ }^{3}$ Kandungan sendiri berarti barang apa yang terkandung (termuat, tercantum di dalamnya); kantung peranakan dalam perut ibu atau janin yang masih di dalam perut ibu. ${ }^{4}$

Menurut sebagian ulama menggugurkan kandungan merupakan sesuatu yang sangat dilarang oleh Allah swt., karena dalam hal ini secara tidak langsung masuk ke dalam kategori membunuh jiwa manusia, dan hal tersebut termasuk kategori dosa besar sebagaimana dijelaskan oleh Imam Al-Ẓahābi dalam kitabnya "Al-Kabāir", bahkan ia tergolong dalam ketegori dosa besar yang kedua ${ }^{5}$, hal tersebut sejalan dengan yang dijelaskan oleh Allah swt. dalam QS. al-Nisā' /4: 93:

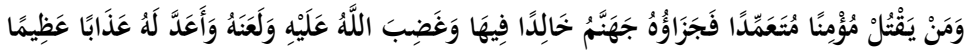

\footnotetext{
${ }^{1}$ Muhammad Ali al-Bār, Musykilatul Ijhāḍ;Dirāsah Tiibbiyah Fiqhiyah (Cet I; Dār al-Sa'udiyah, 1985) h. 10.

${ }^{2}$ Guru Besar Fakultas Syariah dan Undang-Undang Kairo, Qadāya Fiqhiyah Al-Muāṣirah (Maktabah Al-Azhar, 2001) juz 3, h. 293.

${ }^{3}$ Dendy Sugono, Kamus Besar Bahasa Indonesia (Jakarta: Pusat Bahasa, 2008), h. 491.

${ }^{4}$ Dendy Sugono, Kamus Besar Bahasa Indonesia (Jakarta: Pusat Bahasa, 2008), h. 631.

5Imam al-Zahābi, Al-Kabāir "Dosa-Dosa Besar" (Cet. V; Maktabah Malik Fahd Al-Wațaniah; 2007), h. 23.
} 
“Dan barangsiapa yang membunuh seorang mukmin dengan sengaja, Maka balasannya ialah Jahannam, kekal ia didalamnya dan Allah murka kepadanya, dan mengutukinya serta menyediakan ażab yang besar baginya." (QS. al-Nisā' /4: 93) 6

Begitu juga dengan penjelasan yang dipaparkan oleh Rasulullah saw., dalam salah satu hadisnya yang berbunyi:

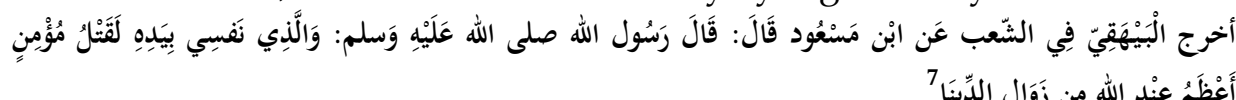

“Dikeluarkan oleh Baihaki dalam al-Sya'bi dan ia dari Ibnu Mas'ud, bahwa Rasulullah saw. bersabda: "Demi Allah yang nyawaku berada dalam genggamannya: Sungguh, pembunuhan atas seorang mukmin itu lebih besar daripada luluh lantahnya dunia disisi Allah swt."

Namun dalam hal pengguguran kandungan dari hasil pemerkosaan ini, apakah masuk dalam kategori dosa besar dan suatu hal yang dilarang oleh Allah swt. sebagaimana pendapat sebagian ulama, ataukah mungkin adakah keringanan khusus yang diberikan oleh Allah kepada mereka, korban pemerkosaan tersebut? Dalam hal ini, Yusuf al- Qardhawi berpendapat bahwa pada dasarnya menggugurkan kandungan merupakan suatu tindak kejahatan dan hukumnya haram atau tidak diperbolehkan, karena itu disebut juga pembunuhan terhadap cikal bakal kehidupan. Akan tetapi, jika menggugurkan kandungan karena tidak ada udzur apapun dan jika dilakukan sebelum ruh ditiupkan yaitu sebelum kehamilan berusia 40 hari, maka yang menggugurkan kandungan tersebut bisa dikenai hukuman, membayar girrah atau kafarat yaitu memerdekakan seorang budak, jika tidak mampu melakukan hal tersebut, diharuskan berpuasa selama dua bulan berturut-turut. ${ }^{8}$

Kemudian, bagi wanita korban pemerkosaan yang hamil, apakah dibolehkan menggugurkan kandungannya? Yusuf alQaradhawi sebelum menguraikan hukum menggugurkan kandungan korban pemerkosaan, ia menjelaskan bahwa korban pemerkosaan tersebut tidak mendapatkan dosa akibat tindak perzinaan (pemerkosaan) yang dilakukan pelaku. Dalam hal ini Yusuf alQardhawi berpendapat bahwa perbuatan yang dilakukan dalam keterpaksaan bahkan dengan ancaman senjata tidak dapat dijatuhi hukum.

${ }^{6}$ Khadïm al-Haramain al-Syarifain, Al-Qur'ān dan Terjemahan Maknanya (Komplek Percetakan Al-Qur'ān Al-Karim Raja Fahd, T.th), h. 136.

${ }^{7}$ Imam al-Zahābi, Al-Kabāir "Dosa-Dosa Besar", h. 25

8 Yusuf al-Qardhawi, Hadyu Islam Fatawi Mu'ashirah, Fatwa-fatwa Kontemporer, Terj. As'ad Yasin, (Jakarta : Gema Insani Press, 1995), h.. 
Dari berbagai masalah tersebut penulis berusaha untuk mengungkap dan memaparkan bagaimana hukum menggugurkan kandungan hasil pemerkosaan menurut Yusuf al-Qardhawi, sehingga dapat memberikan kejelasan hukum bagi permasalahan tersebut di masa sekarang ini. Kemudian bagaimana metode yang digunakan oleh Yusuf al-Qardhawi dalam pengistimbatan hukum menggugurkan kandungan hasil pemerkosaan. Mengingat metode pengistimbatan hukum menjadi sebuah hal yang penting dalam melahirkan sebuah keputusan dan kepastian hukum, khususnya dalam permasalahan menggugurkan kandungan hasil pemerkosaan.

\section{Analisis Terhadap Pendapat Yusuf Al-Qardhawi Tentang Hukum Aborsi Hasil Pemerkosaan}

Aborsi yang dilakukan dengan sengaja tanpa dasar indikasi medis atau tidak dalam keadaan darurat, mayoritas ulama menyatakan keharamannya. Hal ini sesuai dengan makna secara zahir dalil tentang larangan aborsi tersebut. Adapun aborsi (bukan akibat perkosaan) pada dasarnya adalah perbuatan terlarang sejak bertemunya sel sperma laki-laki dengan ovum perempuan, yang dari keduanya muncul makhluk yang baru dan menetap di dalam tempat menetapnya yang kuat yaitu di dalam rahim. Maka makhluk itu harus dihormati meskipun ia hasil dari hubungan yang haram seperti zina. Rasulullah SAW telah memerintahkan wanita Ghamidiyah yang mengaku telah berbuat zina yang akan dijatuhi hukuman rajam itu agar menunggu sampai wanita tersebut melahirkan anaknya, kemudian dia disuruh menunggu sampai anaknya tidak menyusu lagi dan setelah itu baru dijatuhi hukuman rajam. Fatwa tersebut dipilih apabila dalam keadaan normal. ${ }^{9}$

Sedangkan pemerkosaan merupakan pengalaman yang traumatis terhadap jiwa bagi orang yang diperkosa, jika pemerkosaan itu mengakibatkan kehamilan dan selanjutnya kelahiran anaknya akan mengingatkan pada pria yang memperkosanya. Pemerkosaan merupakan kejahatan seksual, namun pemerkosaan tidak sama dengan perzinaan dan pergaulan bebas pada umumnya, karena pemerkosaan terdapat unsur pemaksaan dan kekerasan

Yusuf al-Qardhawi memperbolehkan aborsi akibat pemerkosaan karena kehamilan tersebut (kehamilan wanita korban pemerkosaan) bukan karena mereka berbuat dosa dan bukan pula atas kehendak mereka sendiri. Korban pemerkosaan tidak menanggung dosa sama sekali terhadap apa yang terjadi pada diri mereka selama mereka sudah berusaha menolak dan memeranginya. Kemudian mereka dipaksa di bawah tekanan kekuatan besar pada saat itu apa yang

\footnotetext{
${ }^{9}$ Yusuf Qardhawi, Reformasi Pemikiran Abad 21, (Surabaya: PT. Bina Ilmu, 1998), hlm. 44
} 
dapat dilakukan oleh seorang wanita yang tidak punya kekuatan selain terpaksa melakukannya. Allah sendiri telah menetralisasi dosa (yakni tidak menganggap dosa) dari orang yang terpaksa dalam masalah yang lebih besar daripada zina, yaitu kekafiran dan mengucapkan kalimat kufur. ${ }^{10}$ Sebagaimana firman Allah SWT dalam surat an-Nahl ayat 106:

Artinya: "Barangsiapa yang kafir kepada Allah sesudah dia beriman (dia mendapat kemurkaan Allah), kecuali orang yang dipaksa kafir padahal hatinya tetap tenang dalam beriman (dia tidak berdosa)".

Rasulullah SAW bersabda :

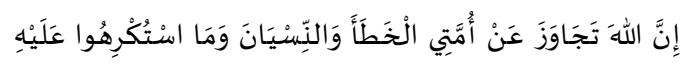

Artinya: "Sesungguhnya Allah menggugurkan dosa dari umatku atas suatu perbuatan yang dilakukannya karena khilaf (tidak sengaja), karena lupa dan karena dipaksa melakukannya". (HR. Ibnu Majah). ${ }^{11}$

Dibolehkannya aborsi akibat perkosaan juga dengan berdasarkan pada surat al-Baqarah ayat 173. Artinya: "Sesungguhnya Allah hanya mengharamkan bagimu bangkai, darah, daging babi, dan binatang yang (ketika disembelih) disebut (nama) selain Allah. tetapi Barangsiapa dalam Keadaan terpaksa (memakannya) sedang Dia tidak menginginkannya dan tidak (pula) melampaui batas, Maka tidak ada dosa baginya. Sesungguhnya Allah Maha Pengampun lagi Maha Penyayang".

Aborsi akibat pemerkosaan menurut Yusuf al-Qardhawi lebih lanjut dibolehkan apabila hal tersebut terjadi sebelum kandungan berusia 40 hari, udzurnya semakin kuat, maka rukhshahhnya semakin jelas, yang demikian itu lebih dekat pada kebolehan. ${ }^{12}$

Dalam ushul fiqih apabila terjadi pertentangan diantara dua pilihan yang memiliki dalil syara' dan sama kuatnya disebut sebagai tazahum. Dengan ketentuan "mendahulukan hukum yang menyempit diatas hukum yang memberi keleluasaan, mendahulukan yang ada penggantinya diatas yang tidak ada penggantinya, utamakan sesuatu yang sudah ditentukan diatas sesuatu yang memberi pilihan, mendahulukan yang lebih penting diatas yang penting, mendahulukan yang lebih berbahaya diatas yang berbahaya. ${ }^{13}$

${ }^{10}$ Yusuf Qardhawi, Fatwa-fatwa Kontemporer, Terj. Al-Hamid Al-Husaini, (Bandung: Pustaka Hidayah, 2000), hlm. 877.

11 Ibnu Majah, Al-Thalaq, hadits nomor 2045, juz I, 659.

${ }^{12}$ Yusuf Qardhawi, Fatwa-fatwa Kontemporer, hlm. 880.

${ }^{13}$ Muhammad Muslehuddin, Hukum Darurat Dalam Islam, (Bandung: 
Dalam melihat masalah digunakan tazahum yaitu mendahulukan hukum yang menyempit diatas hukum yang memberi keleluasaan, dalam kaidah fiqih disebutkan:

$$
\text { إذا تعارض الحقوق قدم منها المضيق على الموسع و الفور على التراخى }
$$

Artinya: "Apabila saling bertentangan ketentuan hokum maka dahulukan yang waktunya sempit daripada yang longgar dan dahulukan yang menghendaki segera daripada yang boleh ditunda". ${ }^{14}$

Pada kehamilan akibat pemerkosaan, ada dua pilihan, antara harus memilih keselamatan janin atau keselamatan ibunya. Ibu merupakan pokok dan janin lahir dari pokok, berdasarkan kaidah ushul fiqih yaitu "mendahulukan yang lebih penting diatas yang penting", maka harus mendahulukan kehidupan ibu diatas kehidupan anaknya. Ibu masih mungkin melahirkan anak-anaknya dan ibu tidak bisa digantikan. Dengan menggunakan kaidah "mendahulukan yang lebih berbahaya diatas yang berbahaya", maka dapat dilihat apakah akan menelantarkan kehidupan ibu dan anaknya selama bertahuntahun atau menolongnya dengan melakukan aborsi yang malang tersebut, mana yang lebih ringan bahayanya.

Lebih lanjut menurut Yusuf al-Qardhawi, bagi perempuan yang terkena musibah tersebut bahkan akan mendapat pahala apabila mereka tetap berpegang teguh pada Islam. Rasulullah SAW bersabda

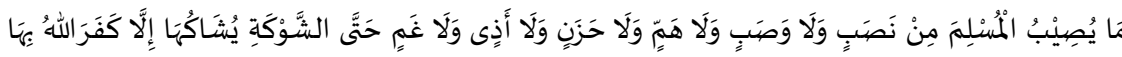

$$
\begin{aligned}
& \text { مِنْ خَطَايَاُُ }
\end{aligned}
$$

Artinya: "Tiada seorang muslim yang menderita kelelahan, penyakit, kesusahan, kesedihan, gangguan atau kerisuhan, bahkan gangguan berupa tertusuk duri, melainkan Allah akan menghapus dosa-dosanya dengan peristiwa-peristiwa itu". (H.R Bukhari) ${ }^{15}$

Sudah jelas bahwa aborsi akibat perkosaan yang dibolehkan Yusuf al-Qardhawi adalah apabila udzurnya yang semakin kuat maka rukhsohnya semakin jelas dan bila hal itu terjadi sebalum berusia 40 hari, maka hal tersebut lebih dekat kepada rukhshah (kebolehan). ${ }^{16}$ Oleh karena itu maka tidak diragukan lagi bahwa pemerkosa adalah orang durhaka yang melampaui batas dan pendosa terhadap perempuan muslimah yang bersih dan suci, merupakan uzur yang kuat bagi korban pemerkosaan dan keluarganya karena ingin terbebas dari trauma tersebut. Maka ini merupakan rukhshah yang difatwakan karena darurat, dan darurat itu diukur dengan kadar ukurannya (dengan akibat yang ada).

Pustaka,1985), hlm. 54.

\footnotetext{
${ }^{14}$ Ibid.

${ }^{15}$ Yusuf Qardhawi, Fatwa-fatwa Kontemporer, hlm. 879.

${ }^{16}$ Ibid., hlm. 880.
} 
Dalam kaidah fiqih disebutkan:

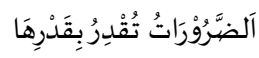

Artinya: "Keadaan darurat itu ditentukan ukurannya menurut kadarnya". 17

Karena itu rukhshah terikat dengan kondisi uzur yang dibenarkan dan ditentukan oleh syara', dokter, cendekiawan, sedangkan yang kondisinya tidak demikian maka tetap termasuk dalam hukum asal yaitu terlarang.

\section{Analisis Metode Istinbat Hukum Yusuf Al-Qardhawi Mengenai Kebolehan Aborsi Akibat Pemerkosaan}

Sebagai seorang mujtahid Yusuf al-Qardhawi mempunyai karakter fiqih tersendiri yang mempengaruhinya dalam mengambil istinbath hukum, beliau berpandangan tidak jauh berbeda dengan imam-imam mazhab terdahulu yaitu melalui tahapantahapan mengambil hukum berdasarkan apa yang telah ditetapkan al-Qur'an, jika tidak didapatinya maka ia pun menetapkannya dengan ketetapan sunnah, dengan berusaha untuk mendapatkan pemahaman yang benar tentang nash-nash yang ada pada keduaanya, dan jika ia tidak mendapati di dalam sunnah, ia pun mencari di dalam ijma' sahabat dan jika ia tidak mendapati dalam ijma' maka ia pun mengambil qiyas disitu.

Dalam penetapan kebolehan hukum melakukan aborsi ini Yusuf al-Qardhawi menggali hukum dengan qiyas yaitu menyamakan hukum yang tidak ada nashnya dengan hukum yang sudah ada nashnya lantaran adanya persamaan illat hukum dari keduanya. ${ }^{18}$ Illat yang digunakan oleh Yusuf al-Qardhawi dalam hal ini adalah berkembang (nama) sebagai salah satu obyek aborsi yang berbarti diperbolehkannya hukum aborsi terhadap kehamilan Ibu yang dalam keadaan darurat, karena disebabkan oleh hal-hal tertentu karena ini demi tercapainya kemaslahatan ummat.

Menurut Yusuf al-Qardhawi diperbolehkanya seorang wanita hamil melakukan aborsi yaitu harus ada alasan-alasan yang kongkrit yaitu adanya kondisi udzur yang muktabar (dibenarkan), yang ditentukan oleh ahli syara', dokter dan cendekiawan, jika kehamilan tersebut tetap dilanjutkan maka akan membahayakan bagi kesehatan Ibu. ${ }^{19}$

Hal ini juga diperkuat oleh sabda Rasulullah tentang keringanan melakukan suatu yang dilarang jika dalam keadaan darurat, sebagaimana ditegaskan dalam hadis sebagai berikut :

${ }^{17}$ Asmuni Abdurrahman, Qaidah-qaidah Fiqh, hlm. 28.

${ }^{18}$ Yusuf al-Qardhawi, Fiqih Praktis Bagi Kehidupan Modren, Terj. Abdul Hayyie Al-Kattani dkk, (Jakarta: Gema Insani Press, 2002), hlm. 91.

${ }^{19}$ Yusuf Qardhawi, Fatwa-fatwa Kontemporer, hlm. 776. 
عن ابن عباس رضي الله عنهما: ان رسول الله صلى الله عليه و سلام قال: إن الله تجاوز لى عن أمتي

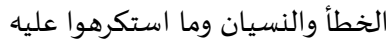

Artinya: Ibnu Abbas ra. Berkata, Rasulullah SAW bersabda, "Sesungguhnya Allah mengampuni beberapa kesalahan umatku yang disebabkan keliru, lupa, dan karena dipaksa." (H.R. Ibnu Majah, Baihaqi, dan lain-lain) ${ }^{20}$

Maksud hadis diatas yaitu diperbolehkannya melakukan suatu yang dilarang ketika berada dalam keadaan darurat, karena hal tersebut merupakan prinsip keuniversalan agama Islam, itulah prinsip yang tidak dicampuri dengan kesukaran. Sebuah keringanan yang diberikan pada hamba-Nya dengan menghapus dosa-dosanya ketika dalam keadaan darurat.

Imam Hambali mengqiyaskan dengan membolehkan melakukan aborsi karena dalam keadaan darurat dan aborsi ini diperbolehkan sebelum terjadinya penciptaan yaitu sebelum janin berusia 40 hari. Adanya keterangan boleh meminum obat-obatan peluntur untuk menggugurkan nutfah. Sebagian kelompok ini mengatakan bahwa boleh meminum obat untuk menggugurkan zighat. $^{21}$

Sedangkan Imam Al-Ghazali mengqiyaskan dengan tidak membolehkan melakukan aborsi walaupun dalam keadaan darurat sekalipun. Al-Ghazali berpendapat bahwa melakukan aborsi pada hakekatnya adalah melakukan kejahatan terhadap makhluk hidup dan Beliau mengharamkan secara mutlak melakuakn aborsi. Disini dikatakan keberadaan makhluk hidup terjadi beberapa fase, fase yang pertama yaitu bersarangnya sperma kedalam rahim dan bebrcampur dengan ovum kemudian siap menghadapi kehidupan, merusak ini termasuk kejahatan. Jika sperma telah menjadi segumpal darah, maka tindakan aborsi tersebut lebih kejam, dan jika telah ditiupkan roh dan sudah sempurna kejadiannya, maka tindakan aborsi lebih kejam lagi kadar kejahatannya. ${ }^{22}$

Al-Ghazali menggambarkan perihal konsepsi percampuran antara sperma dan ovum sebagai sebuah transaksi serahterima (ijabqobul) yang sudah disepakati dan tidak boleh dirusak. Hal ini secara hukum fikih dilarang dan pelakunya wajib dikenai hukuman. Adapun hukumannya yaitu apabila telah berbenntuk segumpal darah (alaqah) maka hukumannya yaitu 1/3 dari denda sempurna (ghurrah kamilah), jika berbentuk segumpal daging (mudgah) dendanya yaitu $2 / 3$, jika telah melewati masa penyawaan pelakunya

${ }^{20}$ Imam An-Nawawi, Terjemahan Hadis Arba' in, (Jakarta: Al-I'tisham Cahaya Umat, 2008), hlm. 61-62.

${ }^{21}$ Maria Ulfa Anshor, Fiqih Aborsi, (Jakarta : Buku Kompas, 2006), hlm. 66.

${ }^{22}$ Yusuf al-Qardhawi, Halal dan Haram Dalam Islam, ( Jakarta : Bina Ilmu, 1997), hlm. 276. 
dihukum dengan membayar denda penuh (gurrah kamilah), jika gugur dalam keadaan meninggal, tetapi sebaliknya, pelaku diwajibkan membayar uang tebusan penuh (diyat kamilah). ${ }^{23}$

Yusuf al-Qardhawi berpendapat bahwa diperbolehkannya melakukan aborsi apabila udzurnya semakin kuat, maka rukhsahnya juga semakin jelas. ${ }^{24}$ Adapun alasan al-Qardhawi dalam hal ini adalah; pertama, adanya berbagai pendapat mengenai hukum aborsi yang menurut Yusuf al-Qardhawi perbedaan tersebut terlalu mencolok, sehingga ia mengambil jalan tengah dari berbagai pendapat tersebut. Kedua, karena adanya berbagai hal, seperti keberadaan kandungan yang jelas- jelas itu menyebabkan kematian ibunya tanpa bisa dihindari. Syari'at memerintahkan melakukan tindakan yang resikonya lebih ringan. Apabila keberadaannya menyebabkan kematian dan tidak ada cara lain untuk menyelamatkan jiwa ibunya kecuali dengan aborsi maka melakukan aborsi menjadi wajib, karena ibu juga merupakan pilar keluarga yang memiliki hak hidup secara mandiri, memiliki hak dan kewajiban. ${ }^{25}$

Adanya perbedaan dalam hukum apakah diperbolehkannya melakukan aborsi adalah tergantung pada sebab dan akibat dilakukannya aborsi. Sehingga sebagai jalan tengah dari perbedaan hukum melakukan aborsi Yusuf al-Qardhawi mengqiyaskan dengan kebolehan melakukan aborsi apabila udzurnya semakin kuat, maka rukhsahsnya semakin jelas dan bila aborsinya dilakukan jika usia kehamilan itu sebelum berusia 40 hari.

Dari paparan diatas, menurut penulis pendapat Yusuf alQardhawi tentang diperbolehkannya melakukan aborsi yang berbeda dengan ulama lain, bila melihat dan memahami illat yang dikemukakan dalam menggunakan qiyas dan tahapan-tahapan yang ditempuh, Yusuf al-Qardhawi tidak berbeda dengan ulama-ulama lain, dalam hal ini dari segi kekuatan illat nya Yusuf al- Qardhawi menggunakan qiyas musawi karena sifat hukum yang dianggap illat dalam kebolehan melakukan aborsi menurut imam Hambali sama kuatnya dengan pendapatnya kebolehan melakukan aborsi menurut Yusuf al-Qardhawi.

\section{Manfaat Diperbolehkannya Melakukan Aborsi Hasil Pemerkosaan Menurut Yusuf Al-Qardhawi}

Kehamilan merupakan sebuah hadiah dan juga merupakan sebuah titipan yang diberikan oleh Allah SWT kepada manusia untuk dijaga dan dipelihara keberadaannya. Namun dalam beberapa kasus, ada yang bahagia dengan kehadiran sang janin tapi tidak jarang dalam

\footnotetext{
${ }^{23}$ Maria Ulfa Anshor, Fiqih Aborsi, hlm. 99.

${ }^{24}$ Yusuf Qardhawi, Fatwa-fatwa Kontemporer, hlm. 880.

${ }^{25}$ Ibid., 289.
} 
beberapa kejadian seorang wanita malah merasa sedih, resah bahkan stress dengan kehamilannya karena kehamilannya merupakan akibat pemerkosaan.

Dalam menetapkan kebolehan hukum aborsi akibat pemerkosaan Yusuf al- Qardhawi mempetimbangkan berbagai hal diantaranya seperti keberadaan kandungan yang jelas-jelas itu menyebabkan kematian ibunya tanpa bisa dihindari dan trauma yang berkepanjangan bagi korban pemerkosaan, selama aborsi tersebut resikonya lebih ringan. Pada hakikatnya aborsi itu haram dilakukan oleh seorang wanita yang sedang hamil, namun apabila dampak yang ditimbulkan dari melanjutkan kehamilan tersebut adalah merupakan sesuatu yang sangat beresiko, ditakutkan akan menyebabkan kemudaratan yang besar bagi si ibu, maka aborsi ini boleh saja dilakukan namun sebelum usia kehamilan berusia 40 hari.

Manfaat diperbolehkannya borsi hasil pemerkosaan ini adalah kemaslahatan bagi korban pemerkosaan. Walaupun pemerkosaan sesungguhnya sama dengan perbuatan zina, karena keduanya terjadi tanpa kerelaan. Kalau pemerkosaan terjadi karena tanpa kerelaan dari seorang wanita, maka zina-pun terjadi tanpa kerelaan kaluarga. Artinya hukum daripada aborsi akibat pemerkosaan sama dengan hukum aborsi hasil perzinahan. Namun yang menjadi titik perbedaan antara keduanya adalah kalau pemerkosaan tidak dikenakan hukuman atau had dalam Islam, sedangkan zina dikenakan had.

\section{Simpulan}

Dari pembahasan terhadap permasalahan di atas, dapat disimpulkan sebagai berikut.

1. Hukum aborsi akibat pemerkosaan menurut Yusuf al-Qardhawi adalah diperbolehkan karena sebagai rukhsah bagi seorang wanita yang hamil akibat pemerkosaan, karena ada sebab-sebab tertentu yang menyebabkan terganggunya keselamatan seorang wanita hamil apabila tidak dilakukan aborsi. Dan aborsi ini dilakukan apabila kehamilan itu berusia sebelum empat puluh hari.

2. Metode istinbath Yusuf al-Qardhawi dalam menetapkan kebolehan melakukan aborsi akibat pemerkosaan adalah qiyas yaitu diperbolehkannya hukum aborsi terhadap seorang wanita yang dalam keadaan dharurat, karena disebabkan oleh hal-hal tertentu, karena dikhawatirkan jika tidak dilakukan aborsi akan membahayakan keselamatan seorang wanita hamil, yang mana seorang wanita adalah pokok adanya janin tersebut, Dan aborsi ini dilakukan ketika kehamilan berusia sebelum empat puluh hari. Hal ini merupakan sifat moderatnya Yusuf al- 
Qardhawi dalam memandang kemaslahatan umat.

\section{Daftar Pustaka}

Dendy Sugono, Kamus Besar Bahasa Indonesia, Jakarta: Pusat Bahasa, 2008.

Imam An-Nawawi, Terjemahan Hadis Arba'in, Jakarta: Al-I'tisham Cahaya Umat Khadïm al-Ḥaramain al-Syarifain, Al-Qur'ān dan Terjemahan Maknanya, Komplek Percetakan Al-Qur'ān AlKarim Raja Fahd, T.t

Maria Ulfa Anshor, Fiqih Aborsi, Jakarta : Buku Kompas, 2006.

Muhammad Ali al-Bār, Musykilatul Ijhäḍ;Dirāsah Țibbiyah Fiqhiyah, Dār al-Sa'udiyah, 1985.

Muhammad Muslehuddin, Hukum Darurat Dalam Islam, Bandung: Pustaka,Imam al-Zahābi, Al-Kabāir "Dosa-Dosa Besar" Maktabah Malik Fahd Al-Wațaniah; 2007.

Yusuf al-Qardhawi, Hadyu Islam Fatawi Mu'ashirah, Fatwa-fatwa Kontemporer, Terj. As'ad Yasin, Jakarta: Gema Insani Press.

Yusuf Qardhawi, Reformasi Pemikiran Abad 21, Surabaya: PT. Bina Ilmu, 1998.

Yusuf Qardhawi, Fatwa-fatwa Kontemporer, Terj. Al-Hamid Al-Husaini,

1985. Bandung: Pustaka Hidayah, 2000.

Yusuf al-Qardhawi, Fiqih Praktis Bagi Kehidupan Modren, Terj. Abdul Hayyie Al-Kattani dkk, Jakarta: Gema Insani Press, 2002., 2008.

Yusuf al-Qardhawi, Halal dan Haram Dalam Islam, Jakarta : Bina Ilmu, 1997. 